\title{
Network value and optimum analysis on the mode of networked marketing in TV media
}

\author{
${ }^{1}$ Dongpo Xiao, 'Zhenji Zhang, ${ }^{2}$ Xiaolan Guan \\ ${ }^{1}$ Beijing Jiaotong University, ${ }^{2}$ Beijing Institute of Graphic Communication (China) \\ xdp100@188.com, zhjzhang@,bjtu.edu.cn,08113101@,bjtu.edu.cn
}

Received August 2012

Accepted November 2012

\section{Abstract:}

Purpose: With the development of the networked marketing in TV media, it is important to do the research on network value and optimum analysis in this field.

Design/methodology/approach: According to the research on the mode of networked marketing in TV media and Correlation theory, the essence of media marketing is creating, spreading and transferring values. The Participants of marketing value activities are in network, and value activities proceed in networked form. Network capability is important to TV media marketing activities.

Findings: This article raises the direction of research of analysis and optimization about network based on the mode of networked marketing in TV media by studying TV media marketing Development Mechanism, network analysis and network value structure.

Keywords: TV media Networked Marketing network analysis, the network value and optimization

\section{Network marketing development mechanism}

Network capability is the source of obtaining sustainable competition Advantage for enterprises. It is the capability of developing the network comprehensive level and managing particular network relationship for enterprise. It is the ability of starting keeping and applying the commercial relationship network to achieving competitive advantages for enterprises. It is the summation of processing network relations and managing network position capability. It contains the following four capabilities, including the enterprise network strategic capability, network operation capability network relations capability and network occupied capability. 
The essence of networked marketing is marketing values whole process of the Network creation and transmission. The Traditional Marketing Theory and the Relationship Marketing Theory cannot solve the questions about value of customers, because the lead function is narrow and the adaptive background is limited. The Modern Marketing Theory is based on the following premise: the strategy of an enterprise is to finish the business goal by designing how to meet the needs of customers. Therefore, the topics of Transaction marketing theory and the Relationship-Marketing theory are both at analyzing and achieving the goals and needs of both enterprises and customers. When enterprises formulated marketing strategies, they just considered the needs of customers but ignored the influence on them from other competitors.

The operation ways of marketing are remodeled and changed by Internet, globalization and competition. Customer Value, core competence and cooperation network have become the three big factors that built the market. At the background of building of new economy, customers can get Real-time and comprehensive messages in lower cost. They can interact with seller and other customers. They can have more choice for the goods and services, even search for seller on their own. In this case, customer behavior was influenced deeply by customer feature, social structure and linkage of customers.

Customer behavior which not only is influenced by the group relationship of customers but also needs social value such as entity of value of the products, Linking value.

Social network marketing experts present a new process about the creation, transfer and communication of networking based on the point of Social Network Theory, Analytic Network Process and network embeddedness, which is the network-oriented Networked Marketing.

The basic of Networked Marketing is social network, which is a system that made up by customers and their multiple correlations. Its essence is a series of social bond or social relations that link the actors which form the social structure in a relatively stable way. All social behaviors are in and can be influenced by the social network which made up by an informal relationship.

\section{TV media networked marketing process analysis}

Network capability is an economic activity that plays a main role in promoting economic value in TV media marketing, which realizes in the system of dynamic network social relations and appreciates by embedding the relevant network medium. Network capability also plays a main role in affecting transmission mechanism of TV media marketing.

The connotation of networked marketing is that enterprises and customers are both in some kind of social network which contains available social resources of producing customers' value. When the marketers use those network resources to creating and transferring values, the network externalities will militate and affect the performance because of embedding. 
There has been lots of researches that combined marketing with process to analyze. Marketing campaign is embeded in the main process of three creating customer value and enterprise value. Compare the traditional marketing, the relationship marketing and the Network marketing model in their main process, this article will construct network marketing theory according to them.

\begin{tabular}{|c|c|c|c|}
\hline marketing mode & \multicolumn{3}{|c|}{ Business process } \\
\hline $\begin{array}{c}\text { traditional marketing } \\
\text { (transaction-oriented) }\end{array}$ & $\begin{array}{c}\text { Film and television product } \\
\text { development management process }\end{array}$ & $\begin{array}{c}\text { Resource provider } \\
\text { management process }\end{array}$ & $\begin{array}{c}\text { Customer relationship } \\
\text { management process }\end{array}$ \\
\hline & $\begin{array}{c}\text { Design and develop the products } \\
\text { that can make the customer value } \\
\text { maximization and create customer } \\
\text { satisfaction }\end{array}$ & $\begin{array}{c}\text { sign a series of contracts } \\
\text { with external resource } \\
\text { provider }\end{array}$ & $\begin{array}{c}\text { Identifying, locating, } \\
\text { selling, transfering and } \\
\text { serving } \\
\text { tools: } 4 \mathrm{P}^{\prime} \mathrm{S}\end{array}$ \\
\hline $\begin{array}{c}\text { relationship marketing } \\
\text { (relationship-oriented) }\end{array}$ & $\begin{array}{c}\text { Find a series of relations from both } \\
\text { internal and external }\end{array}$ & $\begin{array}{c}\text { develop the relations with } \\
\text { external resource provider }\end{array}$ & $\begin{array}{c}\text { Develop, cultivate and } \\
\text { promote customer groups } \\
\text { andividual relations: } \\
4 R^{\prime} S\end{array}$ \\
\hline $\begin{array}{c}\text { Network to network } \\
\text { marketing } \\
\text { (network oriented) }\end{array}$ & $\begin{array}{c}\text { Lead and participate in many } \\
\text { different networks and diffuse } \\
\text { cultivate and integrate product } \\
\text { development }\end{array}$ & $\begin{array}{c}\text { Lead and participate in } \\
\text { many different supply } \\
\text { network to create resource } \\
\text { supply, improve the } \\
\text { efficiency of resources }\end{array}$ & $\begin{array}{c}\text { identify and satisfy } \\
\text { customers' demands by } \\
\text { developing and managing } \\
\text { the network }\end{array}$ \\
\hline
\end{tabular}

Table 1. Content contrast of three kinds of marketing mode in the main business process

According to the summary of form 1 , the theoretical framework of networked marketing mode will set up on the three key Business process which are PDM, SCM and CRM in this article. The main practical activities of networked marketing are $3 \mathrm{~N}^{\prime} \mathrm{S}$ process, they are: (1) network analysis: identify and analyze the current and potential network in enterprises to explore the content, location and speciality of the customer value (2) network building: confirm the network objects to build and develop the route to build so that customer value and its supporter can be created (3) network optimization: manage the network in the dynamic way. Maintain, optimize and quit the problem. Spread, transfer and upgrade value.

\section{Analysis of TV media networked marketing model}

Value activities are controlled by enterprises, customers, third-parties and support groups. Value exploration needs marketers identifying and analyzing the network they are in or want to be in so that they can realize the display of customer value, the capability of assessing enterprises and the resource space of holding resource. The three periods of the strategy forming in Network strategy are recognition network form, analysis of the network relationship and analysis of the network structure. 


\subsection{Recognition network form}

\begin{tabular}{|l|l|}
\hline Distinguishing criterion & Topology \\
\hline Organization location & External network and self network (Dimaggio \& Louch, 1998; Zaheer \& Bell, 2005) \\
Network members & $\begin{array}{l}\text { Customer network, supplier network, competitors network and reseller network } \\
\text { (Ustuer \& Godes,2006) }\end{array}$ \\
\hline $\begin{array}{l}\text { Network relations } \\
\text { essence }\end{array}$ & $\begin{array}{l}\text { Social network (Berry, 1983; Gronroos, 1983, 1990; Gummesson, 1987; Levitt, 1981; } \\
\text { Business Network(Anderson, Hakanson \& Johanson, 1994) } \\
\text { Institutional network (Granovetter, 2005,2007; Nelason, 1982; Wilkinson, 2002) }\end{array}$ \\
\hline Network structure & Close Network and open Network (Bourdieu, 1980; Coleman, 1992) \\
\hline Network resources & Emotional product information and technical network ect. \\
\hline $\begin{array}{l}\text { Network maintenance } \\
\text { time }\end{array}$ & $\begin{array}{l}\text { Long duration Network (Deconstructed firm, Strategic, Value-added partnership) } \\
\text { (Johnston \& Lawrence,1988; Verity) } \\
\text { Short duration Network (virtual corporation) }\end{array}$ \\
\hline
\end{tabular}

Table 2. Classification of TV media networked marketing network form

\subsection{Analysis of the network relationship}

Networking TV media's marketing research and advance can affect the creation and delivery of customer value. In the network marketing, it is necessary to learn from the point of view of social network theory, when analyze the characteristics of the network relationship, join the analysis of relationship strength. The relationship is divided into strong ties and weak ties, strong ties have higher reliability of the information, but the information is easy to be homogeneous; But the information from weak ties is more novel and heterogeneous, it can improve the performance of the actors. The strong relationship and weak relationship in the cluster network can affect the creation and the influence of explicit knowledge and tacit knowledge, the strong relationship is considered to be more conducive to the tacit knowledge communication, and the weak relationship is more beneficial to the explicit knowledge communication. Therefore, enterprise in spreading value must be clear about the information content and nature, then, decide to establish a strong relationship or a weak relationship. Analysis of online relationships significance lies in, the significance of analysis the network relationship is that, through the analysis of the quality and strength in the network, we can get an initial way to reach a network, thus, we have the premise of using the externality, to reduce the cost of value creation, dissemination and delivery.

\subsection{Analysis of the network structure}

Network status is a key dimension in the network structure, it determines the ultimate effect of marketing campaigns. The consumers with greater social solidarity residing in the highest value in a social network status, they are very important to the results of marketing campaigns. The efficiency and effectiveness of network value creation, dissemination, and delivery depends on the mastery of externality of network resources, depends on the following four variables: 
- Centrality. The higher the centrality, the more opportunities actors can guide and get the resources, they can occupy a key position in the network.

- Structural autonomy. It occupies the actors in structure, it can be faster and more effective to enjoy the resources in the internet, by blocking the flow of information or distorting the information content in the process of information transfer, in order to control the other actors, forming the authority relationship between network structure.

- Structure balance. When the relationships in the network become more balanced, actors would consciously avoid direct conflict in the network, and the network will more stabilized.

- Network density. High density network make it easier to develop shared norms of mutual trust relations, and the common patterns of behavior; high density network also shorten the average path of information passing, speed up the flow of information, and also conducive to the rapid spread of innovative knowledge and results.

\section{Basing the network build on network capability and value creation of television media}

Through network analysis, we can clear that where the marketers in network and the value form of network customers, enterprise value creation space and network resource distribution, so we can develop a variety of marketing strategies, through the marketing activities for the formation of the network and entrance.

\subsection{Basing the construction of relationship between self network and external network on network level}

Basing the construction of self network on business enterprise level and relationship level, we can through these three ways: First of all, we can through the tribal marketing and accept the entry conditions, create the "network consensus", let the enterprise embed in a network, forming a self network. Secondly, by internalizing and participating, absorbing new actors, forming a self network. Thirdly, by accepting and internalizing social norms and interface rules, realizing the construction of self network.

Basing the marketing on self network and external network, there are two levels of network embedded: in low level, by structural analysis of the two networks, identifying the common Third party, as the embedded object and bridges, to realize the nesting of two different networks. In High level, the highest cost income is: Find out the structure hole between two core actors of networks, looking for or to set up a third party in that position, strengthening the bilateral relationship with third party, as a bridge between the two core actors of networks, forming a core relationship among networks, to realize the nesting of two different networks. 


\subsection{The network optimization of TV media network marketing mode}

\begin{tabular}{|c|c|c|c|}
\hline Mode & Transaction marketing model & Relationship marketing model & Network marketing model \\
\hline Guide & Transaction & Relationship & Network \\
\hline $\begin{array}{l}\text { Research } \\
\text { contents }\end{array}$ & $\begin{array}{l}\text { Target market and marketing mix } \\
\text { strategy which take the } \\
\text { customers as the core }\end{array}$ & $\begin{array}{l}\text { To keep the customers as the } \\
\text { center of the customer } \\
\text { relationship management }\end{array}$ & $\begin{array}{l}\text { Network construction and } \\
\text { development take network value } \\
\text { activity as the core }\end{array}$ \\
\hline Analytical basis & $\begin{array}{l}\text { Economics, Management, } \\
\text { Behavioral Science and } \\
\text { Psychology etc }\end{array}$ & New institutional economics etc & $\begin{array}{l}\text { Consumers, Customer } \\
\text { relationship and Related } \\
\text { network }\end{array}$ \\
\hline $\begin{array}{c}\text { The research } \\
\text { object }\end{array}$ & Consumers & Customer relationship & $\begin{array}{l}\text { Consumers, Customer } \\
\text { relationship and Related } \\
\text { network }\end{array}$ \\
\hline $\begin{array}{c}\text { Basic human } \\
\text { nature } \\
\text { hypothesis }\end{array}$ & $\begin{array}{l}\text { Agent, Social man, Profit } \\
\text { maximization }\end{array}$ & $\begin{array}{l}\text { Agent, Social man, cultured } \\
\text { people, Network people, } \\
\text { Reasonable profit }\end{array}$ & $\begin{array}{l}\text { Agent, Social man, cultured } \\
\text { people, Network people, Profit } \\
\text { sharing }\end{array}$ \\
\hline $\begin{array}{l}\text { Social patterns } \\
\text { of practice }\end{array}$ & $\begin{array}{l}\text { Industrial society, Mechanized } \\
\text { production }\end{array}$ & $\begin{array}{l}\text { Post-industrial society, Service } \\
\text { Economy, Perceptual consumption } \\
\text { era }\end{array}$ & $\begin{array}{l}\text { Post-industrial society, New } \\
\text { economy }\end{array}$ \\
\hline Key Concepts & $\begin{array}{l}\text { Demand, Target Customer, } \\
\text { Market segmentation, Market } \\
\text { positioning, Marketing Mix }\end{array}$ & $\begin{array}{l}\text { Customers satisfaction degree, } \\
\text { Customer Retention, Customer } \\
\text { Loyalty, Trust, Promise }\end{array}$ & $\begin{array}{l}\text { Network, Dive relationship, } \\
\text { Network capability, Integrated } \\
\text { value, Network marketing } \\
\text { process }\end{array}$ \\
\hline Marketing Tools & $\begin{array}{l}\text { Basing } 4 \mathrm{P}^{\prime} \mathrm{S} \text { on differences of } \\
\text { customers }\end{array}$ & $\begin{array}{l}\text { Basing 4P'S on Relationship } \\
\text { differentiation }\end{array}$ & Basing $3 N^{\prime} S$ on Value network \\
\hline Customer Value & $\begin{array}{l}\text { Product entity value(Function } \\
\text { interests and Emotional benefits) }\end{array}$ & $\begin{array}{l}\text { Entity value of products or } \\
\text { services and Symbol value } \\
\text { (Function interests and Emotional } \\
\text { benefits, } \\
\text { Relationship benefits) }\end{array}$ & $\begin{array}{l}\text { Integrated value provided by } \\
\text { network(Function interests, } \\
\text { Emotional benefits, Relationship } \\
\text { benefits and Social value of } \\
\text { products and services) }\end{array}$ \\
\hline $\begin{array}{l}\text { Positioning } \\
\text { Marketing }\end{array}$ & $\begin{array}{l}\text { Necessary activities used for } \\
\text { problem solving and decision } \\
\text { making }\end{array}$ & $\begin{array}{l}\text { Interactive activities of enterprise } \\
\text { and consumers and other } \\
\text { stakeholders }\end{array}$ & $\begin{array}{l}\text { A series of activities and social } \\
\text { process of the enterprises in } \\
\text { network total creation, spread } \\
\text { and transfer value }\end{array}$ \\
\hline
\end{tabular}

Table 3. Comparison of network marketing model with transaction marketing model and relationship marketing model

From the perspective of relationship dimensions, the network configuration of TV media network marketing mode has interpersonal, commercial and institutional three aspects: Firstly, using salesmen themselves, to manage the external embedding network of interpersonal relationship network of senior person such as "boundary" for marketing benefits; Secondly, adopting an enterprise level product upgrades, creating common value, bilateral pricing, Networking channel, IMC and the externality of economic relation network of specific corporate marketing strategies to enter the network and reap the marketing benefits; Thirdly, using the externality of network practice and network culture of enterprise network organization to enter the network and reap the marketing benefits. We can compare the network marketing model with the transaction marketing model and the relationship marketing model deeply to analyze how to optimize the network of TV media network marketing model. As shown in table 3.

In short, TV media network marketing is not terminated in the construction of the network, we also need a good network capability to keep the network running and healthy, to ensure that the value in network can be healthy and normal spread and transfer, this will require the network support and the network optimization, even when necessary we must exit the network, in order 
to search for the new value to network reconfiguration. And the basis of these decisions depends on the controllable variable that can affect the network capacity, to regulate the marketing performance, through the causal relationship between network capability and the performance of value activities to decide whether or not to sustain the network, how to optimize the network and how to exit the network.

\section{Conclusion}

The research contents of TV media network marketing mode surround that how the enterprise expand for network operation and management, it is based on the customer, relationship, network source, marketing ability, market information, network capability and other core concepts, it breaks the 4P' frame which based on traditional customer differentiation, the 4R's framework which based on relationship marketing category and the $3 \mathrm{~N}$ 's tool which based on exploration, creation, dissemination and transfer of the network value. In this paper, to the enterprise no matter inside or outside, we regard all actors who are related to the value activities as the research object, paying attention to the long-term development of the whole environment of TV media network marketing, it opens up a new research field.

In future studies, we also need to analyze how the social network promote or restrict the generation and transmission of the integrity value from the network level. To consider from the actor's level and bilateral level, we tried to explain the mechanism of action, evolution process and specific path that how marketing enterprise embedded in the customer network. To consider from actor's level and relation level, we deepened the understanding of the traditional relationship marketing, increased the customer value.

\section{References}

Achrol, R. (1997). Changes in the theory of interorganizational relations in marketing: Towards a network paradigm . Journal of the Academy of Marketing Science, 25(1), 56-71. http://dx.doi.org/10.1007/BF02894509

Anand, B., \& Khanna, T. (2000). Do firms learn to create value of the case of alliances. Strategic Management Journal, 21(3), 295-316. http://dx.doi.org/10.1002/(SICI)1097-0266(200003)21:3<295::AID-SMJ91>3.0.CO;2-O

Granovetter, M. (1985). Economic Action and Social Structure: The Problem of Embeddedness . American Journal of Sociology, 9(3), 481-510. http://dx.doi.org/10.1086/228311

Granovetter, M.S. (1973). The strength of weak ties. American Journal of Sociology, 78(6), 1360-1380. http://dx.doi.org/10.1086/225469

Hakansson, H. (1987). Understanding business markets. NewYork: Croom Helm. 
Hansen, M.T. (2002). Knowledge networks: Explaining effective knowledge sharing in multiunit companies. Organization Science, 13(3), 232-248. http://dx.doi.org/10.1287/orsc.13.3.232.2771

Li, L., Yang, W., \& Xie, Y. (2006). Game theoretic analysis of signal selection for network marketing firm. Journal of Industrial Engineering and Engineering Management, 20(4), 135-138.

Pittaway, L., Robertson, M., \& Denyer, N. (2004). Networking and innovation: A systematic review of the evidence. International Journal of Management Reviews, (3/4), 137-168. http://dx.doi.org/10.1111/j.1460-8545.2004.00101.x

Ranft, A.L., \& Lord, M.D. (2002). Acquiring new technologies and capabilities, a grounded model of acquisition implementation. Organization Science, 13(4), 420-441. http://dx.doi.org/10.1287/orsc.13.4.420.2952

Ren, F., Wang, K., \& Cheng, L. (2004). Empirical study on the relation between internet use and sales performance. Journal of Industrial Engineering and Engineering Management, 18(4), 109-112.

Ritter, T. (1999). The networking company: Antecedents for coping with relationships and networks effectively. Industrial Marketing Management, 28(5), 467-479. http://dx.doi.org/10.1016/S0019-8501(99)00075-9

Ritter, G. (2003). Network competence: Its impact on innovation success and its antecedents. Journal of Business Research, 56, 745-755. http://dx.doi.org/10.1016/S0148-2963(01)00259-4

Uzzi, B. (1996). The sources and consequences of embeddedness for the economic performance of organizations: the network effect. American sociological review, 61(4), 647-698. http://dx.doi.org/10.2307/2096399

Zhao, S., \& Xiao, H. (2010). Study on the increasing paths of firm performance based on network capability. Science and Technology Progress and Policy. 
Journal of Industrial Engineering and Management, 2012 (www.jiem.org)

@)

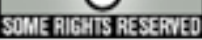

El artículo está con Reconocimiento-NoComercial 3.0 de Creative Commons. Puede copiarlo, distribuirlo y comunicarlo públicamente siempre que cite a su autor y a Intangible Capital. No lo utilice para fines comerciales. La licencia completa se puede consultar en http://creativecommons.org/licenses/by-nc/3.0/es/ 